\section{Energy intake underreporting of adults in a household survey: the impact of using a population specific basal metabolic rate equation}

\author{
Subestimativa da ingestão energética em amostra \\ probabilística de adultos: o impacto do uso de \\ equações específicas para taxa metabólica basal
}

\author{
Subestimación de la ingesta energética en una \\ muestra probabilística de adultos: el impacto \\ del uso de ecuaciones específicas para la tasa \\ metabólica basal
}

Danielle Ribeiro de Souza 1

Luiz Antonio Anjos 1

Vivian Wahrlich 1

Mauricio Teixeira Leite de Vasconcellos 2
1 Universidade Federal Fluminense, Niterói, Brasil.

2 Instituto Brasileiro de Geografia e Estatística, Rio de Janeiro, Brasil.

Correspondência D. R. Souza

Universidade Federal Fluminense.

Rua Mário Santos Braga 30 Niterói, RJ 24020-140, Brasil. danynutry@hotmail.com

\begin{abstract}
The purpose of the present study was to identify energy intake (EI) underreporting and to estimate the impact of using a population specific equation for the basal metabolic rate (BMR) in a probability sample of adults from Niterói, Rio de Janeiro State, Brazil. A sample of 1,726 subjects participated in the study. EI was assessed by a 24-hour dietary recall and EI/BMR was computed with BMR estimated using internationally recommended equations as well as specific equations developed for the adult population of Niterói. Mean EI was 1,570.9 and 2,188.8kcal. day-1 for women and men, respectively. EI decreased with increasing age in both men and women. BMR estimated by the Brazilian equation was significantly lower than the values estimated by the international equation for all age, sex and nutritional status groups. In general, EI underreporting was found in at least $50 \%$ of the population, higher in women, and increased with increasing age and body mass index (BMI). The results of the present study confirm that EI is underreported, even when BMR is estimated using population-specific equations.
\end{abstract}

Energy Intake; Basal Metabolism; Eating; Diet Surveys; Adults

\section{Resumo}

O objetivo do presente estudo foi identificar a subestimativa da ingestão energética (IE) e estimar o impacto do uso de uma equação específica da população para a taxa metabólica basal (TMB), em amostra probabilística de adultos do Município de Niterói, Rio de Janeiro, Brasil. Uma amostra de 1.726 indivíduos da população adulta participou do estudo. Ingestão energética foi avaliada por um recordatório de 24 horas e IE/TMB foi calculada com TMB estimada pelas equações recomendadas e pelas equações específicas para a população. A média da IE foi 1.570,9 e 2.188,8kcal.dia-1 em mulheres e homens, respectivamente. A ingestão energética diminuiu com o aumento da idade em homens e mulheres. A taxa metabólica basal estimada pela equação brasileira foi significativamente menor do que os valores estimados pela equação recomendada para todas as idades, sexo e estado nutricional. Em geral, a subestimativa da IE foi encontrada em pelo menos $50 \%$ da população, maior em mulheres, e aumentou com o avanço da idade e índice de massa corporal (IMC). Os resultados confirmam que IE é subestimada, mesmo quando a TMB é estimada pelas equações da população específica.

Ingestão de Energia; Metabolismo Basal; Ingestão de Alimentos; Inquéritos sobre Dietas; Adultos 


\section{Introduction}

The assessment of individuals' dietary patterns is considered to be an important procedure to identify early nutritional status changes which may help prevent the emergence of diseases 1 . However, the detection of associations between food intake and the risk of diseases in population studies may be limited by the difficulty in measuring intake accurately. Data from studies using the doubly labeled water (DLW) technique have shown that some individuals 2 tend to underreport energy intake (EI). In general, EI underreporting increases with increasing age 3 , is higher in women than in men and is more prevalent among overweight and obese individuals 4,5. According to Goldberg et al. 6 , the ratio between EI and the basal metabolic rate (BMR) can be used to establish criteria for under and over reporting of EI. Mean values of EI below 1.35 times the BMR in individuals with stable body mass can serve as the cutoff point for detecting EI underreporting because it would be statistically unlikely that such a value would represent the usual intake. The cutoff value may, however, be different depending on the number of subjects being assessed, the number of days of EI assessment, the nutritional status and whether BMR is measured or predicted $6,7,8$.

The problems with the numerator, estimated EI, have been documented extensively in the literature 1 . However, little attention has been given to the denominator. BMR is important not only in the assessment of the validity of EI information in population studies but also in the determination of the energy requirements of populations and in the expression of physical activity levels 9 . Since it is not routinely measured, BMR is estimated by predictive equations 9,10 , but some studies have shown that these equations overestimate BMR in Brazilians living in the country 11 and abroad 12 . A recent report has documented the inadequacy of the Food and Agriculture Organization/World Health Organization (FAO/WHO) recommended BMR equations 9,10 in a probability sample of adults from Niterói, Rio de Janeiro State, Brazil 11. Predicted BMR was significantly higher than measured BMR in men and women of all ages, leading the authors to develop 11 and validate 12 equations to estimate BMR for the adult population of Niterói. Thus, reliable BMR information is crucial when assessing EI in population studies. To this end, the purpose of the present study was to identify EI underreporting using the EI/BMR ratio based on the BMR estimated using internationally recommended and Brazilian-specific predictive equations, according to the age and nutritional status of the adult population of $\mathrm{Ni}$ - terói. The hypothesis was that the frequency of underreporting would be lower when population-specific BMR equations were used in the analysis.

\section{Materials and methods}

The Nutrition, Physical Activity and Health Survey (PNAFS) was a household survey for which a probability sample of adults ( $\geq 20$ years of age) living in the city of Niterói, was designed in three stages $5,13,14$. In the first stage, 110 census enumeration areas (CEAs) were selected with a probability proportional to the number of household dwellings from an ordered list according to the average household income. This procedure allowed an implicit income stratification of the CEAs. In the second stage, for each selected CEA, 80 households were selected with equal probability to define a basic list used in the inverse sampling procedure 15 similar to that of the World Health Survey in Brazil 16. In the third stage, for each interviewed household, an adult was selected to participate in the study with equal probability among all adults in the household. To be eligible, the adult had to be free of any cardiac or metabolic condition, under no medication that could alter food intake or metabolism, be under no restricted diet or be pregnant.

A first visit was conducted to each selected household to explain the purpose of the study, to obtain written consent and to schedule the beginning of data collection. In the morning of the schedule day, a trained nutritionist conducted a 24 hour dietary recall $(24 \mathrm{hR}) 5$. The interviews were balanced on all weekdays in order to represent the mean intake of the population 1 .

A food photograph album 17 was used to help the subject estimate food portion sizes. If the food item was not present in the album, the size was estimated from other food items present in the album. Each reported food item was converted to grams based on the published food weights of the food photograph album. Foods or preparations reported in household measures were converted to grams using a table for Brazilian kitchenware measures 18 . The size/weight of foods or preparations eaten outside the house was obtained directly from the provider/manufacturer. The reported foods or preparations were converted to energy and macronutrients using computer software developed for the Brazilian cuisine (NutWin; Escola Paulista de Medicina, Universidade Federal de São Paulo, São Paulo, Brazil). For foods or preparations not present in the program, tables of chemical composition of foods were used 19,20. 
Anthropometric measurements were done in the household with the subject barefoot and with as little clothing as possible, usually in the morning. Body mass was measured once with electronic calibrated scales (Soehnle, Murrhardt, Germany) to the nearest $0.1 \mathrm{~kg}$. Stature was measured in duplicate with a portable stadiometer (Seca, Birmingham, UK) attached to a wall. Body mass index (BMI) was calculated as body mass divided by squared stature. $\mathrm{Nu}$ tritional status was determined according to the WHO classification ${ }^{21}$ using the BMI categories $\left(\mathrm{kg} . \mathrm{m}^{-2}\right)$ : underweight $(<18.5)$, adequate (18.5-24.9), overweight (25-29.9), and obese ( $\geq$ 30). BMR for each individual was estimated by predictive equations recommended for international use 9,10 and the ones developed in a sub-sample of the PNAFS 11. The equations are $\mathrm{BMR}=9.99$ (body mass) +7.14 (stature) -2.79 (age in years) -450.5 for males and; BMR $=8.95$ (body mass) +8.87 (stature) -0.70 (age in years) -814.3 for females. EI underreporting was based on the EI/BMR ratio of 1.53 in accordance with the criterion suggested by Goldberg et al. 6 .

Of the 1,760 subjects selected, it was not possible to calculate the EI of 34 individuals due to fasting ( 2 subjects), and incompleteness of the $24 \mathrm{hR}$. Thus, the final sample was composed of 1,726 individuals (1,202 women). Statistical weighting of the data allowed a representation of a total of 324,671 adults from the Niterói population (145,886 men and 178,785 women). Descriptive statistics (mean, standard error SE and 95\% confidence intervals - 95\%CI) were computed using the surveymeans and surveyfrea procedures of SAS (SAS Inst., Cary, USA) which adequately address complex sample designs, using calibrated weights. The significance of the differences of EI, BMR and EI/BMR between age and nutritional status categories were identified when the 95\%CI did not overlap.

The Ethics Research Committee of the Sergio Arouca National School of Public Health, Oswaldo Cruz Foundation approved all research procedures in accordance with the Declaration of Helsinki for protection of human subjects from research risks.

\section{Results}

Mean ( \pm SE) age was $45.3 \pm 0.6$ years for women and $43.0 \pm 0.7$ years for men and mean BMI was $25.5 \pm 0.1 \mathrm{~kg} . \mathrm{m}^{-2}$ and $25.4 \pm 0.2 \mathrm{~kg} \cdot \mathrm{m}^{-2}$, respectively (Table 1). Prevalence of underweight was low (2.9\% and $2.1 \%$ in women and men, respectively) but overweight (32\% and $34.4 \%$ ) and obesity (15.1\% and $13.8 \%$ ) were highly prevalent.
EI was $1,570.9 \pm 24.1 \mathrm{kcal}^{\text {day }}{ }^{-1}$ in women and $2,188.8 \pm 46.1 \mathrm{kcal}^{\text {.day-1 }}{ }^{-1}$ in men. BMR was significantly higher when the Schofield equation was used for estimates $\left(1,512.2 \pm 7.1\right.$ kcal.day-1; $^{-1}$ 95\%CI: 1,498.2; 1,526.3kcal.day-1) compared with the Brazilian equations $\left(1,256.1 \pm 5.8 \mathrm{kcal}_{\text {.day- }}{ }^{-1}\right.$; 95\%CI: $1,244.6$; 1,267.6kcal.day-1) in the population as a whole and in both the female and male population separately (Table 1), representing a difference of approximately $19 \%$ and $21 \%$, respectively.

The results of BMR and EI/BMR according to the age of men and women are presented in Table 2. The highest EI was observed in the 2030 year-old group both in women and men and the lowest in the $\geq 60$ year-old group. There was a progressive and significant decline in EI with increasing age, a phenomenon more evident and pronounced among men (Figure 1a). EI increased with increasing BMI in men but decreased in women (Figure 1b).

Among men, BMR decreased with increasing age, a fact not so clearly identified in women, although BMR was significantly different between the youngest and oldest age groups for both sexes. Since BMR estimated by the Brazilian equations was always lower than the Schofield equations, the mean EI/BMR ratio was always higher when it was calculated using BMR estimated using the Brazilian equations. The lowest EI/ BMR ratios calculated with BMR predicted by the Schofield's equation were found in the 50-60 year age bracket, with values of $1.06 \pm 0.03$ and $1.19 \pm$ 0.05 for women and men respectively (Table 2).

Table 3 presents the results of BMR and EI/ BMR according to the nutritional status of the female and male population. The mean EI/BMR ratio decreased with increasing BMI, a phenomenon more evident in the female population, in whom the EI/BMR ratio of the lowest BMI was significantly higher than the value of the highest BMI (Table 3).

When the EI/BMR ratio was calculated with BMR estimated by the Schofield equations, underreporting was $80.4 \%$ (95\%CI: $77.8 ; 83.0)$ and $72.6 \%$ (95\%CI: $66.1 ; 77.2)$ for women and men respectively. The same values calculated with the Brazilian equations were $66.1 \%$ (95\%CI: 62.9 ; 69.3 ) and 55.6\% (9\%\%CI: 50.9; 60.2). Underreporting was higher in overweight/obese individuals in comparison to underweight subjects, irrespective of the equation used. Table 4 presents the percentage of individuals who underreported EI according to age, nutritional status and sex. With the exceptions of the $\geq 60$ year-old group and the underweight groups, EI underreporting was significantly lower using BMR estimated by the Brazilian equations in women. 
Figure 1

Energy intake (EI) according to age (a) and nutritional status (b), based on the body mass index (BMI; $\mathrm{kg} \cdot \mathrm{m}-2$ ) of the adult female and male population ( $\geq 20$ years). Niterói, Rio de Janeiro State, Brazil.

a) Age (years)

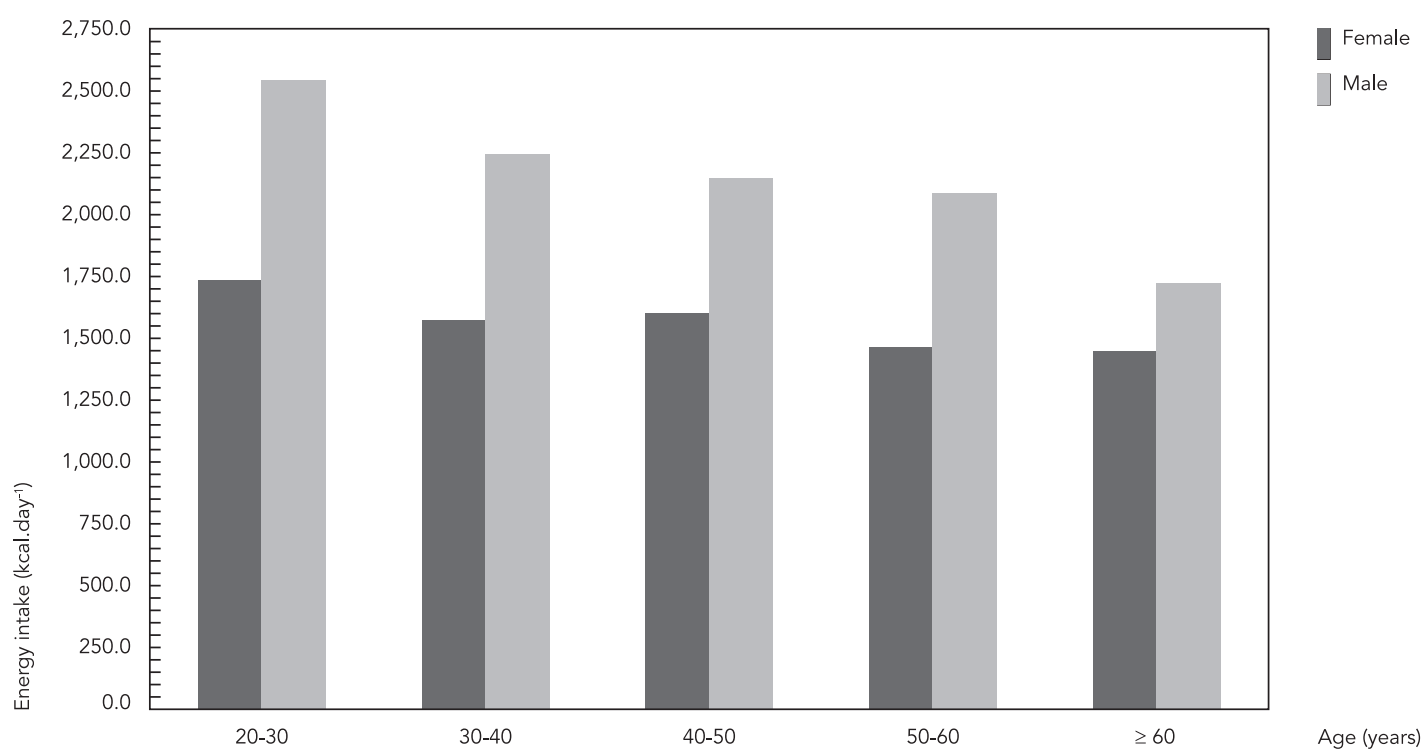

b) Nutritional status

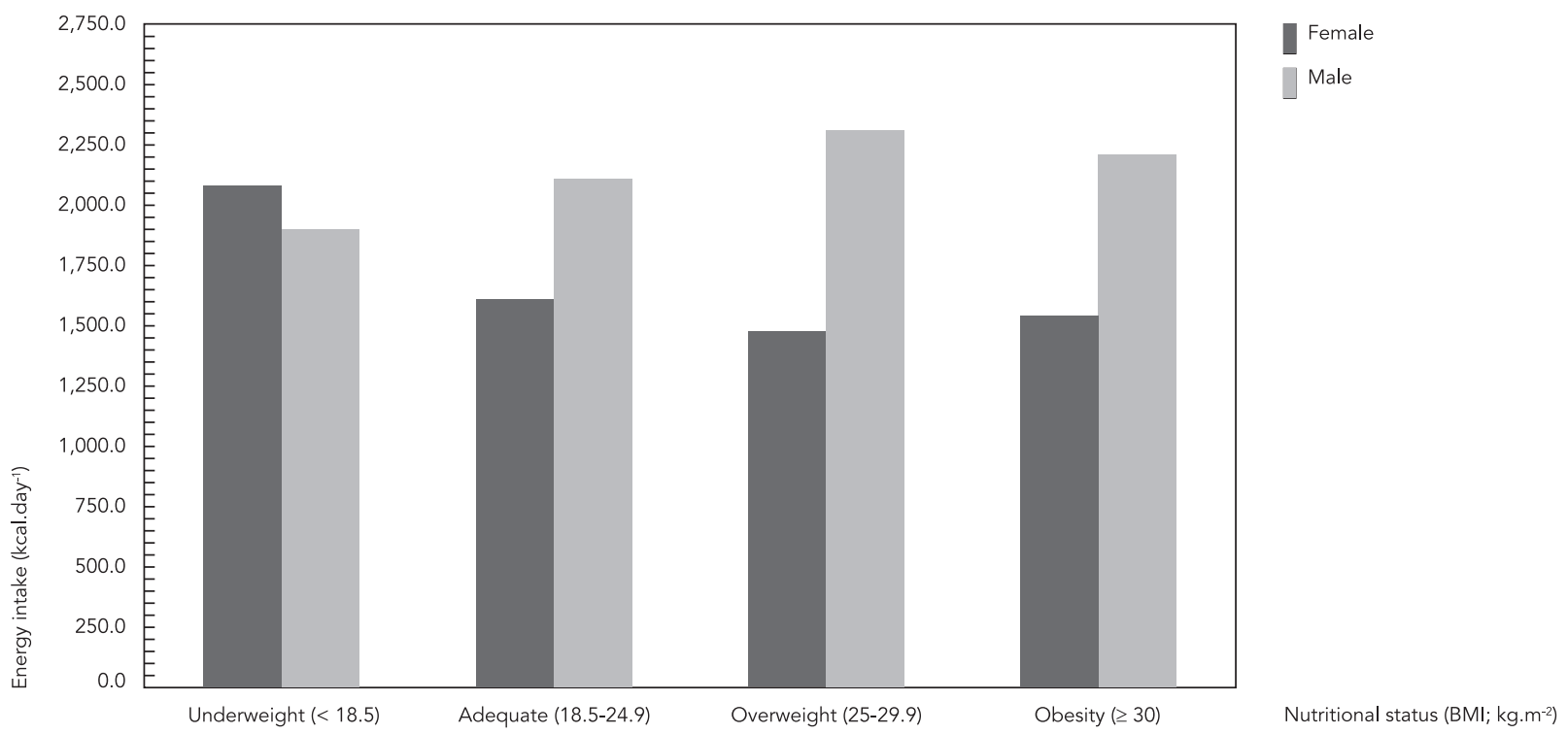


Table 1

Age, anthropometry, energy intake (EI) and estimated basal metabolic rate (BMR) of the adult female and male population ( $\geq 20$ years). Niterói, Rio de Janeiro State, Brazil.

\begin{tabular}{lcccccc}
\hline & \multicolumn{3}{c}{ Female $(\mathbf{n = 1 , 2 0 2})$} & \multicolumn{3}{c}{ Male $(\mathbf{n = 5 2 4 )}$} \\
& Mean & SE & $95 \%$ Cl & Mean & SE & $95 \%$ Cl \\
\hline Age (years) & 45.3 & 0.6 & $44.0 ; 46.6$ & 43.0 & 0.7 & $41.5 ; 44.5$ \\
Body mass (kg) & 64.0 & 0.4 & $63.2 ; 64.7$ & 75.1 & 0.6 & $73.9 ; 76.4$ \\
Stature (cm) & 158.6 & 0.2 & $158.1 ; 159.0$ & 171.8 & 0.3 & $171.1 ; 172.5$ \\
BMI (kg.m-2) & 25.5 & 0.1 & $25.2 ; 25.7$ & 25.4 & 0.2 & $25.1 ; 25.8$ \\
El (kcal.day-1) & $1,570.9$ & 24.1 & $1,523.0 ; 1,618.8$ & $2,188.8$ & 46.1 & $2,097.4 ; 2,280.3$ \\
Estimated BMR (kcal.day-1) & & & & & & \\
Schofield 10 & $1,349.6$ & 4.6 & $1,340.5 ; 1,358.8$ & $1,711.8$ & 10.1 & $1,691.7 ; 1,731.9$ \\
Anjos et al. 11 & $1,134.2$ & 4.3 & $1,125.6 ; 11,42.7$ & $1,405.8$ & 8.6 & $1,388.7 ; 1,423.0$ \\
\hline
\end{tabular}

95\%Cl: 95\% confidence interval; BMI: body mass index; SE: standard error.

BMR equations (kcal.day-1): [Schofield 10: For males: 18-29.9 years, BMR $=15.057$ (body mass in $\mathrm{kg}$ ) + 692.2; 30-59.9 years, $B M R=11.472$ (body mass in $\mathrm{kg}$ ) $+873.1 ;>60$ years, $B M R=11.711$ (body mass in $\mathrm{kg}$ ) + 587.7. For females: 18-29.9 years, $B M R=14.818$ (body mass in $\mathrm{kg}$ ) $+486.6 ; 30-59.9$ years, $B M R=8.126$ (body mass in $\mathrm{kg})+845.6$; $>60$ years, $\mathrm{BMR}=9.082$ (body mass in $\mathrm{kg})+658.5$ ]. Anjos et al. 11 [For males, BMR $=9.99$ (body mass in $\mathrm{kg})+7.14$ (stature in $\mathrm{cm})-2.79$ (age in years) - 450.5. For females, $\mathrm{BMR}=8.95$ (body mass in $\mathrm{kg}$ ) +8.87 (stature in $\mathrm{cm}$ ) -0.70 (age in years) -814.3 ].

Table 2

Measured and estimated basal metabolic rate (BMR) and energy intake (EI) and El/BMR by age of the adult female and male population ( $\geq 20$ years) Niterói, Rio de Janeiro State, Brazil.

\begin{tabular}{|c|c|c|c|c|c|c|c|c|c|c|}
\hline & \multicolumn{10}{|c|}{ Age (years) } \\
\hline & \multicolumn{2}{|c|}{$20-30$} & \multicolumn{2}{|c|}{$30-40$} & \multicolumn{2}{|c|}{$40-50$} & \multicolumn{2}{|c|}{$50-60$} & \multicolumn{2}{|c|}{$\geq 60$} \\
\hline & Mean & SE & Mean & SE & Mean & SE & Mean & SE & Mean & SE \\
\hline \multicolumn{11}{|l|}{ Female } \\
\hline \multicolumn{11}{|l|}{ Estimated BMR (kcal.day-1) } \\
\hline Schofield 10 & $1,397.5$ & $11.4^{a}$ & $1,364.7$ & $6.8^{a, b}$ & $1,378.1$ & $6.0 c$ & $1,391.8$ & $7.2^{\mathrm{b}}$ & $1,229.8$ & $6.5^{a}, b, c$ \\
\hline Anjos et al. 11 & $1,152.3$ & $8.1^{\mathrm{a}}$ & $1,155.6$ & $8.6 b$ & $1,149.0$ & $8.1^{\mathrm{c}}$ & $1,148.3$ & $9.9 \mathrm{~d}$ & $1,070.6$ & $9.1 a, b, c, d$ \\
\hline El/BMR (Schofield 10) & 1.27 & $0.04 a$ & 1.16 & $0.04 b$ & 1.17 & $0.03 c$ & 1.06 & $0.03 a, b, c, d$ & 1.18 & $0.05 d$ \\
\hline El/BMR (Anjos et al. 11) & 1.53 & $0.05 a, b, c$ & 1.38 & $0.04 a$ & 1.41 & $0.03 d$ & 1.29 & $0.04 b, d$ & 1.36 & $0.05 c$ \\
\hline \multicolumn{11}{|l|}{ Male } \\
\hline \multicolumn{11}{|l|}{ Estimated BMR (kcal.day-1) } \\
\hline Schofield 10 & $1,821.7$ & $5.8 a, b, c$ & $1,761.0$ & 16.0a & $1,756.7$ & $15.6 \mathrm{~b}$ & $1,741.3$ & $22.3 \mathrm{c}$ & $1,402.4$ & $14.8 \mathrm{a}, \mathrm{b}, \mathrm{c}$ \\
\hline Anjos et al. 11 & $1,480.5$ & $14.1 \mathrm{a}, \mathrm{c}$ & $1,462.3$ & $18.2 \mathrm{~b}$ & $1,412.6$ & $16.8^{\mathrm{a}}$ & $1,368.1$ & $23.9 \mathrm{c.b}$ & $1,242.9$ & $15.5 a, b$ \\
\hline El/BMR (Schofield 10) & 1.42 & $0.06 a, b, c$ & 1.28 & 0.05 & 1.22 & $0.04 a$ & 1.19 & $0.05 b$ & 1.23 & $0.05^{c}$ \\
\hline El/BMR (Anjos et al. ${ }^{11}$ ) & 1.74 & $0.08 a, b, c, d$ & 1.54 & $0.06^{a}$ & 1.52 & $0.05 b$ & 1.51 & $0.07 c$ & 1.39 & $0.05 d$ \\
\hline
\end{tabular}

SE: standard error.

Note: values with the same letters in superscript indicate that means are different $(p<0.05)$.

BMR equations (kcal.day-1): [Schofield 10: For males: 18-29.9 years, BMR $=15.057$ (body mass in kg) $+692.2 ; 30-59.9$ years, BMR $=11.472$ (body mass in kg) + $873.1 ;>60$ years, BMR $=11.711$ (body mass in $\mathrm{kg}$ ) +587.7 . For females: 18-29.9 years, BMR $=14.818$ (body mass in $\mathrm{kg})+486.6 ; 30-59.9$ years, BMR $=8.126$ (body mass in $\mathrm{kg})+845.6 ;>60$ years, $\mathrm{BMR}=9.082$ (body mass in kg) +658.5 ]. Anjos et al. 11 [For males, BMR $=9.99$ (body mass in kg) +7.14 (stature in $\mathrm{cm})-$ 2.79 (age in years) -450.5 . For females, $B M R=8.95$ (body mass in $\mathrm{kg}$ ) +8.87 (stature in $\mathrm{cm}$ ) -0.70 (age in years) -814.3 ] 
Measured and estimated basal metabolic rate (BMR) and energy intake (EI) and El/BMR according to the nutritional status (body mass index - BMI; kg.m-2) of the adult female and male population ( $\geq 20$ years). Niterói, Rio de Janeiro State, Brazil.

\begin{tabular}{|c|c|c|c|c|c|c|c|c|}
\hline & \multicolumn{8}{|c|}{ Nutritional status (kg.m-2) } \\
\hline & \multicolumn{2}{|c|}{$\begin{array}{l}\text { Underweight } \\
\qquad(<18.5)\end{array}$} & \multicolumn{2}{|c|}{$\begin{array}{c}\text { Adequate } \\
(18.5 \leq \mathrm{BMI}<25)\end{array}$} & \multicolumn{2}{|c|}{$\begin{array}{c}\text { Overweight } \\
(25 \leq \mathrm{BMI}<30)\end{array}$} & \multicolumn{2}{|c|}{$\begin{array}{l}\text { Obesity } \\
\text { ( } \geq 30)\end{array}$} \\
\hline & Mean & SE & Mean & SE & Mean & SE & Mean & SE \\
\hline \multicolumn{9}{|l|}{ Female } \\
\hline \multicolumn{9}{|l|}{ Estimated BMR (kcal.day-1) } \\
\hline Schofield 10 & $1,180.3$ & $9.6 \mathrm{a}$ & $1,287.3$ & $3.6 \mathrm{a}$ & $1,372.0$ & $6.2^{\mathrm{a}}$ & $1,540.8$ & $14.9 a$ \\
\hline Anjos et al. 11 & $1,023.1$ & $13.4 \mathrm{a}$ & $1,077.7$ & $4.5 \mathrm{a}$ & $1,154.2$ & $6.1 \mathrm{a}$ & $1,299.4$ & $12.8 \mathrm{a}$ \\
\hline El/BMR (Schofield 10) & 1.75 & $0.09 a, b$ & 1.25 & $0.02 a, b$ & 1.08 & $0.03 a$ & 1.01 & $0.03 b$ \\
\hline El/BMR (Anjos et al. 11) & 2.04 & $0.11 a, b$ & 1.50 & $0.03 a, b$ & 1.29 & $0.03 a$ & 1.20 & $0.04 b$ \\
\hline \multicolumn{9}{|l|}{ Male } \\
\hline \multicolumn{9}{|l|}{ Estimated BMR (kcal.day-1) } \\
\hline Schofield 10 & $1,386.9$ & $60.3^{a}$ & $1,607.6$ & $10.2^{a}$ & $1,774.2$ & $14.4^{a}$ & $1,982.4$ & $20.6 \mathrm{a}$ \\
\hline Anjos et al. 11 & $1,195.8$ & $43.2^{\mathrm{a}}$ & $1,317.8$ & $9.3^{a}$ & $1,456.0$ & $12.2^{a}$ & $1,630.3$ & $17.7 a$ \\
\hline El/BMR (Schofield 10) & 1.37 & 0.14 & 1.31 & $0.04 a$ & 1.30 & $0.04 b$ & 1.12 & $0.06 a, b$ \\
\hline El/BMR (Anjos et al. 11) & 1.57 & 0.15 & 1.59 & $0.05 a$ & 1.59 & $0.05 b$ & 1.37 & $0.07 a, b$ \\
\hline
\end{tabular}

SE: standard error.

Note: values with the same letters in superscript indicate that means are different $(p<0.05)$.

BMR equations (kcal.day-1): [Schofield 10: For males: 18-29.9 years, BMR $=15.057$ (body mass in kg) $+692.2 ; 30-59.9$ years, BMR $=11.472($ body mass in kg) + $873.1 ;>60$ years, BMR $=11.711$ (body mass in $\mathrm{kg})+587.7$. For females: 18-29.9 years, BMR $=14.818$ (body mass in $\mathrm{kg})+486.6 ; 30-59.9$ years, BMR $=8.126$ (body mass in kg) +845.6 ; $>60$ years, BMR $=9.082$ (body mass in kg) +658.5$]$. Anjos et al. 11 [For males, BMR $=9.99$ (body mass in kg) +7.14 (stature in cm) 2.79 (age in years) - 450.5. For females, $\mathrm{BMR}=8.95$ (body mass in $\mathrm{kg}$ ) +8.87 (stature in $\mathrm{cm}$ ) -0.70 (age in years) -814.3$]$.

\section{Discussion}

Assessment of the population's EI is important in the context of societies facing demographic transitional changes. The results of this study confirm, for the adult population of Niterói, the nutritional profile documented for the Brazilian population in the latest Household Budget Survey 22: low prevalence of underweight and high prevalence of overweight and obesity.

Dietary data of the adult population of $\mathrm{Ni}$ terói showed that older male and female individuals report eating less, results that confirm the data found in the estimated EI of the population as a whole (1,490 and 1,795kcal.day-1 for the female and male population, respectively), and in the southeastern region where Niterói is located, in the most recent Household Budget Survey ${ }^{23}$.

Since the determination of energy requirements is given by the estimation of energy expenditure calculated, in most cases, as the product of BMR and physical activity level 9, overestimation of energy requirements becomes very critical in obese individuals. Because BMR is rarely measured in clinical or epidemiological studies, pre- dictive equations based on body mass and specific age groups are frequently used ${ }^{9}$. It has been well documented that these equations overestimate BMR 11,12. In fact, BMR values calculated by the equation proposed by Anjos et al. 11 and validated by Wahrlich et al. 12 , specific for the population of Niterói, show that the equations recommended for international use significantly overestimate BMR, confirming the results documented in segments of the Brazilian population living in the country 11 and abroad 24 . The results also showed differences in BMR when stratified by age, sex and nutritional status (BMI), factors that directly influence BMR 25 .

In individuals with excess body mass, negative energy balance (EI-energy expenditure) is often observed when energy expenditure is estimated by BMR x physical activity level, a situation that is not compatible with their nutritional status 5 . There are some basic methodological problems with the generation of such data, which may compromise interpretation. First, several studies of food intake in individuals with excess body mass seem to indicate that this segment of the population underreports EI $4,26,27,28$. One 
Percentage (\%) of underreporting of energy intake (EI), using the 1.53 cut-off criterion based on El to basal metabolic rate (BMR) ratio (EI/BMR) using the Schofield 10 or Anjos et al. 11 BMR predictive equations, according to age and nutritional status (BMl; $\mathrm{kg} \cdot \mathrm{m}-2$ ) of the adult female and male population ( $\geq 20$ years). Niterói, Rio de Janeiro State, Brazil.

\begin{tabular}{|c|c|c|c|c|}
\hline & \multicolumn{2}{|c|}{ Female } & \multicolumn{2}{|c|}{ Male } \\
\hline & Schofield 10 & Anjos et al. 11 & Schofield 10 & Anjos et al. 11 \\
\hline & $\%(95 \% \mathrm{Cl})$ & $\%(95 \% \mathrm{Cl})$ & $\%(95 \% \mathrm{Cl})$ & $\%(95 \% \mathrm{Cl})$ \\
\hline \multicolumn{5}{|l|}{ Age (years) } \\
\hline $20-30$ & $74.5(68.2 ; 80.7)$ & $58.7(51.4 ; 66.1)$ & $61.3(51.6 ; 71.0)$ & $48.2(38.6 ; 57.9)$ \\
\hline $30-40$ & $84.9(79.8 ; 89.9)$ & $72.5(66.5 ; 78.6)$ & $71.6(62.8 ; 80.4)$ & $55.1(45.2 ; 64.9)$ \\
\hline $40-50$ & $78.8(73.5 ; 84.0)$ & $61.8(55.8 ; 67.8)$ & $75.4(66.8 ; 84.0)$ & $55.2(45.8 ; 64.5)$ \\
\hline $50-60$ & $87.5(83.1 ; 91.8)$ & $69.9(62.5 ; 77.4)$ & $83.3(72.1 ; 94.5)$ & $56.7(42.3 ; 71.2)$ \\
\hline$\geq 60$ & $78.7(71.8 ; 85.6)$ & $68.7(61.0 ; 76.5)$ & $78.4(67.7 ; 89.1)$ & $66.5(54.5 ; 78.5)$ \\
\hline \multicolumn{5}{|l|}{ Nutritional status (kg.m-2) } \\
\hline Underweight (BMI < 18.5) & $31.8(13.6 ; 49.9)$ & $27.5(10.6 ; 44.5)$ & $55.3(9.2 ; 100.0)$ & $46.9(2.2 ; 91.5)$ \\
\hline Adequate $(18.5 \leq \mathrm{BMI}<25)$ & $77.5(73.7 ; 81.3)$ & $60.7(56.2 ; 65.2)$ & $71.0(64.6 ; 77.3)$ & $52.4(45.4 ; 59.2)$ \\
\hline Overweight $(25 \leq \mathrm{BMI}<30)$ & $84.7(80.5 ; 88.8)$ & $72.4(67.4 ; 77.3)$ & $71.0(63.4 ; 78.5)$ & $55.7(47.6 ; 63.8)$ \\
\hline Obesity (BMI $\geq 30$ ) & $90.3(85.7 ; 94.9)$ & $78.1(71.4 ; 84.8)$ & $85.5(74.7 ; 96.4)$ & $68.0(55.9 ; 80.2)$ \\
\hline
\end{tabular}

95\% Cl: 95\% confidence interval.

BMR equations ( $k$ cal.day-1): [Schofield 10: For males: 18-29.9 years, BMR $=15.057$ (body mass in kg) $+692.2 ; 30-59.9$ years, BMR $=11.472$ (body mass in kg) + $873.1 ;>60$ years, $B M R=11.711$ (body mass in $\mathrm{kg})+587.7$. For females: 18-29.9 years, BMR $=14.818$ (body mass in $\mathrm{kg})+486.6 ; 30-59.9$ years, BMR $=8.126$ (body mass in $\mathrm{kg})+845.6 ;>60$ years, $\mathrm{BMR}=9.082$ (body mass in $\mathrm{kg})+658.5]$. Anjos et al. 11 [For males, BMR $=9.99($ body mass in $\mathrm{kg})+7.14$ (stature in $\mathrm{cm})-$ 2.79 (age in years) - 450.5. For females, $\mathrm{BMR}=8.95$ (body mass in $\mathrm{kg}$ ) +8.87 (stature in $\mathrm{cm}$ ) -0.70 (age in years) -814.3 ]

possibility to identify EI under (or over) reporting is the calculation of the EI/BMR ratio. The cutoff values for the ratio were developed assuming that energy requirement equals EI for sedentary individuals whose body mass remains stable.

In the present study, the EI/BMR ratio was lower in overweight and obese individuals, with significant differences in each BMI category, confirming data from other studies 4,6,26,27,28,29. The EI/BMR ratio was close to 1 for obese individuals indicating an inadequate case of equality of EI and BMR. However, this has already been reported in the literature: in a sample of 215 middle-aged, low-income, low-literate Caribbean Latino population at risk of developing type 2 diabetes ( $78 \%$ were obese), mean EI/estimated BMR was $1.03 \pm 0.37$ and was lower in individuals with higher BMI 30 . The EI/BMR values of the American population investigated in the various waves of the National Health and $\mathrm{Nu}$ trition Examination Survey (NHANES) since 1971 have been shown to be 1.31 and 1.19 for men and women, respectively 31 . This shows how difficult it is to trust self-report EI measurements especially if BMR (or energy expenditure) is not measured or adequately estimated.

It is important to highlight that the EI/BMR values were always lower when the population- specific BMR equations were used in the pres ent study. This is due to the difference in BMR estimated by the two sets of equations $(\approx 20 \%)$. It is recognized that BMR is overestimated by general prediction equations in some populations 9,11. EI/BMR data from the third phase of the NHANES decreased with increasing BMI 32 , which may have been due to the lower value of the numerator (underreporting) and overestimation of the denominator, overestimation of BMR based on the increasing values of body mass 8 . Individuals with greater body mass expend more energy to move their body mass, meaning that their energy intake will have to be higher to maintain their greater body mass, a fact documented in the publications on energy requirements by the Institute of Medicine 33 and FAO/WHO 9. The fact that BMR is higher in individuals with higher body mass may explain the data found in the adult population of Niterói, in whom the EI/ BMR ratio was lower in subjects with higher BMI. Estimated energy expenditure in the same population 34 showed that as BMI increased energy expenditure also increased.

EI underreporting has been estimated to vary widely (10-45\%) depending on age, sex and body composition 27,28,29,35. Underreporting increases 
with age 3 , is higher in women and is more prevalent among overweight and obese individuals $4,5,25$. The results of the present study confirm these findings. EI underreporting increased with increasing BMI. It is worth noting that except for underweight individuals, all age and nutritional status groups presented more than $50 \%$ of EI underreporting. Schoeller 2 has reported this as the usual level of underreporting found in energy expenditures studies using DLW. This technique can be used to identify EI underreporting if one assumes that the energy expenditure equals EI when body mass and composition are stable 29 . However, the method is too costly to be used in large epidemiological studies. Thus, it is imperative that accurate estimation of BMR (preferably measured) be used in health-related nutrition studies to ascertain the quality of EI information and its associations.

The accurate estimate of dietary intake remains a challenge but the $24 \mathrm{hR}$ is still considered an adequate method to determine the EI of large samples of individuals when all days of the week are assessed ${ }^{9}$ despite the problems with memory, food size estimation and the food chemical composition tables. In the present study only one $24 \mathrm{hR}$ was obtained in a probability sample of adults in a household survey which might be considered a limitation. Because dietary intake of an individual is not constant from day to day, an understanding of the variability in food intake is required to estimate usual intake. Variability in food intake arises both because each individual differs in the types and amounts of food ingested from one day to the next 36,37 and because individuals differ from each other in their food intakes (between- or inter-subject variability) 1 . Thus, the $24 \mathrm{~h}$ dietary recall method is believed to represent the usual dietary intake of individuals when it is repeated in a number of days depending on the nutrient of interest ${ }^{1}$. However, a single $24 \mathrm{hR}$ can represent the mean intake of groups of individuals in dietary surveys given that all days of the week are assessed in a probability sample of the population 1 as was done in the present study. This procedure has been performed in large population surveys 7 .

\section{Conclusion}

The results of the present study confirm that EI is underreported, especially in individuals with excess body mass. It is crucial that BMR be adequately estimated when it is not possible to measure it if the purpose is to identify EI underreporting. 


\section{Resumen:}

El objetivo del presente estudio fue identificar la subestimación de la ingesta energética (IE) y estimar el impacto del uso de una ecuación específica de la población para la tasa metabólica basal (TMB), en una mues tra probabilística de adultos del municipio de Niterói, Río de Janeiro, Brasil. Una muestra de 1.726 individuos de la población adulta participó en el estudio. La ingesta energética fue evaluada mediante un recordatorio de 24 horas y las IE/TMB fueron calculadas con una TMB estimada por las ecuaciones recomendadas y por las ecuaciones específicas para la población. La media de la IE fue 1.570, 9 y 2.188,8kcal.día-1 en mujeres y hombres, respectivamente. La ingesta energética disminuyó con el aumento de la edad en hombres y mujeres. La tasa metabólica basal estimada por la ecuación brasileña fue significativamente menor que los valores estimados por la ecuación recomendada para todas las edades, sexo y estado nutricional. En general, la subestimación de la IE se encontró en por lo menos un $50 \%$ de la población, fue mayor en mujeres y aumentó con el aumento de la edad e índice de masa corporal (IMC). Los resultados confirman que la IE está subestimada, incluso cuando la TMB está estimada por las ecuaciones de población específica.

Ingestión de Energía; Metabolismo Basal; Ingestión de Alimentos; Encuestas sobre Dietas; Adultos

\section{References}

1. Gibson RS. Principles of nutritional assessment $2^{\text {nd }}$ Ed. New York: Oxford University Press; 2005.

2. Schoeller DA. Limitations in the assessment of dietary energy intake by self-reported. Metabolism 1995; 44(2 Suppl 2):18-22.

3. Livingstone MB, Prentice AM, Coward WA, Strain JJ, Black AE, Davies PSW, et al. Validation of estimates of energy intake by weighed dietary record and diet history in children and adolescents. Am J Clin Nutr 1992; 56:29-35.

4. Rodrigues AE, Marostegan PF, Mancini MC, Dalcanale L, Melo ME, Cercato C, et al. Analysis of resting metabolic rate evaluated by indirect calorimetry in obese women with low and high caloric intake. Arq Bras Endocrinol Metab 2008; 52:76-84.

5. Souza DR, Anjos LA, Wahrlich V, Vasconcellos MTL Machado JM. Ingestão alimentar e balanço energético da população adulta de Niterói, Rio de Janeiro, Brasil: resultados da Pesquisa de Nutrição, Atividade Física e Saúde (PNAFS). Cad Saúde Pública 2010; 26:879-90.

\section{Contributors}

D. R. Souza supervised the field data collection and was in charge of data analyses, wrote the first draft of the paper, which was revised and approved by the other authors. L. A. Anjos and V. Wahrlich planned the research, supervised the field data collection, were in charge of data analyses, and revised the paper approved by the other authors. M. T. L. Vasconcellos planned the research, designed the sample and calculated the natural and calibrated sampling weights, and revised the paper approved by the other authors.

\section{Acknowledgments}

The study was supported by Fiocruz (PAPES III/2013, n. 250.139) and CNPq (n. 471172/2001-4 and n.475122/2003-8). L. A. Anjos received a research productivity grant from CNPq (n. 305399-2012-8).
6. Goldberg GR, Black AE, Jebb AS, Cole TJ, Murgatroyd PR, Coward WA, et al. Critical evaluation of energy intake data using fundamental principles of energy intake physiology: 1 . Derivation of cutoff limits to identify under-recording. Eur J Clin Nutr 1991; 45:569-81.

7. Briefel RR, McDowell MA, Alaimo K, Caughman $\mathrm{CR}$, Bischof AL, Carroll MD, et al. Total energy intake of the US population: the third National Health and Nutrition Examination Survey, 19881991. Am J Clin Nutr 1995; 62 (5 Suppl):1072S-80S.

8. Anjos LA, Souza DR, Rossato SL. Challenges in food intake assessment in population studies. Rev Nutr 2009; 22:151-61.

9. Food and Agriculture Organization; World Health Organization. Human energy requirements. Report of a Joint $\mathrm{FAO} / \mathrm{WHO} / \mathrm{UNU}$ Expert Consultation. Rome: Food and Agriculture Organization; 2004. (Food and Nutrition Technical Report Series, 1). 
10. Schofield WN. Predicting basal metabolic rate, new standards and review of previous work. Hum Nutr Clin Nutr 1985; 39 Suppl 1:5-41.

11. Anjos LA, Wahrlich V, Vasconcellos MTL. BMR in a Brazilian adult probability sample: the Nutrition, Physical Activity and Health Survey. Public Health Nutr 2014; 17:853-60.

12. Wahrlich V, Anjos LA, Teixeira TM. Basal metabolic rate: validation of a population-specific equation for Brazilians. Ann Nutr Metab 2013; 63 Suppl 1:1039.

13. Bossan FM, Anjos LA, Vasconcellos MTL, Wahrlich V. Nutritional status of the adult population in Niterói, Rio de Janeiro, Brazil: the Nutrition, Physical Activity, and Health Survey. Cad Saúde Pública 2007; 23:1867-76.

14. Anjos LA, Barbosa TBC, Wahrlich V, Vasconcellos MTL. Padrão de atividade física em um dia típico de adultos de Niterói, Rio de Janeiro, Brasil: resultados da Pesquisa de Nutrição, Atividade Física e Saúde (PNAFS). Cad Saúde Pública 2012; 28:1893902.

15. Haldane JB. On a method of estimating frequencies. Biometrika 1945; 33:222-5.

16. Vasconcellos MTL, Silva PLN, Szwarcwald CL. Sampling design for the World Health Survey in Brazil. Cad Saúde Pública 2005; 21 Suppl 1:S89-99.

17. Zabotto CB, Viana RPT, Gil MF. Registro fotográfico para inquéritos dietéticos: utensílios e porções. Campinas: Universidade Estadual de Campinas/ Goiânia: Universidade Federal de Goiás; 1996.

18. Pinheiro ABV, Lacerda EMA, Benzecry EH, Gomes MCS, Costa VM. Tabela para avaliação de consumo alimentar em medidas caseiras. 5a $\underline{\text { Ed}}$. Rio de Janeiro: Editora Atheneu; 1996.

19. Instituto Brasileiro de Geografia e Estatística. Estudo Nacional de Despesa Familiar - ENDEF. Tabelas de composição de alimentos. 3a Ed. Rio de Janeiro: Instituto Brasileiro de Geografia e Estatística; 1985.

20. Ulene A. The Nutribase nutrition facts desk reference: the single encyclopedic source for the most complete, up-to-date and comprehensive collection of food values. New York: Avery Publishing Group; 1995.

21. World Health Organization. Obesity: preventing and managing the global epidemic, report of a WHO consultation. Geneva: World Health Organization; 2000. (WHO Technical Report Series, 894).

22. Instituto Brasileiro de Geografia e Estatística. Antropometria e estado nutricional de crianças, adolescentes e adultos no Brasil: Pesquisa de Orçamentos Familiares 2008-2009. Rio de Janeiro: Instituto Brasileiro de Geografia e Estatística; 2010.

23. Instituto Brasileiro de Geografia e Estatística. Análise do consumo alimentar pessoal no Brasil: Pesquisa de Orçamentos Familiares 2008-2009. Rio de Janeiro: Instituto Brasileiro de Geografia e Estatística; 2011.

24 Wahrlich V, Anjos LA, Going SB, Lohman TG. Basal metabolic rate of Brazilians living in the Southwestern United States. Eur J Clin Nutr 2007; 61:289-93.

25 Heitmann BL, Lissner L. Dietary underreporting by obese individuals: is it specific or non specific? BMJ 1995; 311:986-9.
26 Johansson L, Solvoll K, Bjorneboe GEA, Drevon CA. Under- and overreporting of energy intake related to weight status and lifestyle in a nationwide sample. Am J Clin Nutr 1998; 68:266-74.

27 Rennie KL, Coward A, Jebb SA. Estimating underreporting of energy intake in dietary surveys using an individualised method. Br J Nutr 2007; 97:1169-76.

28 Black AE, Cole TJ. Within- and between-subject variation in energy expenditure measured by the doubly-labelled water technique: implications for validating reported dietary energy intake. Eur J Clin Nutr 2000; 54:386-94.

29 McGowan MJ, Harrington KE, Kiely M, Robson PJ, Livingstone MBE, Gibney MJ. An evaluation of energy intakes and the ratio of energy intake to estimated basal metabolic rate (EI/BMRest) in the North/South Ireland Food Consumption Survey. Public Health Nutr 2008; 4:1043-50.

30 Olendzki BC, Ma Y, Hebert JR, Pagoto SL, Merriam PA, Rosal MC, et al. Underreporting of energy intake and associated factors in a Latino population at risk of developing type 2 diabetes. J Am Diet Assoc 2008; 108:1003-8.

31 Archer E, Hand GA, Blair SN. Validity of U.S. nutritional surveillance: National Health and Nutrition Examination Survey caloric energy intake data, 1971-2010. PLoS One 2013; 8:e76632.

32 Briefel RB, Sempos CT, McDdowell MA, Chien SCY, Alaimo K. Dietary methods research in the third National Health and Nutrition Examination Survey: underreporting of energy intake. Am J Clin Nutr 1997; 65(4 Suppl):1203S-9S.

33 Institute of Medicine. Dietary reference intakes for energy, carbohydrate, fiber, fat, fatty acids, protein, and amino acids. Part 1. Washington DC: National Academy Press; 2002.

34 Anjos LA, Ferreira BCM, Vasconcellos MTL, Wahrlich V. Gasto energético em adultos do município de Niterói, Rio de Janeiro: resultados da Pesquisa de Nutrição, Atividade Física e Saúde - PNAFS. Ciênc Saúde Coletiva 2008; 13:1775-84.

35 Ferrari P, Slimani N, Ciampi A, Trichopoulou A, Naska A, Lauria C, et al. Evaluation of under- and overreporting of energy intake in the 24-hour diet recalls in the European Prospective Investigation into Cancer and Nutrition (EPIC). Public Health Nutr 2002; 5:1329-45.

36 Hall KD, Heymsfield SB, Kemnitz JW, Klein S, Schoeller DA, Speakman JR. Energy balance and its components: implications for body weight regulation. Am J Clin Nutr 2012; 95:989-94.

37 Palaniappan U, Cue RI, Payette H, Gray-Donald K. Implications of day-to-day variability on measurements of usual food and nutrient intakes. J Nutr 2003; 133:232-5.

Submitted on 03/Apr/2014

Final version resubmitted on 26/Sep/2014

Approved on 15/Oct/2014 